\title{
Tourism Object Development Strategy in Rejang Lebong Regency Bengkulu Province
}

\author{
Rani Kurniawati, Ninuk Triyanti, Dahyar Daraba \\ 1,2,3 Institut Pemerintah Dalam Negeri (IPDN), Jatinangor \\ E-mail: rani.kurniawati@gmail.com
}

(Received: February-2019; Reviewed: March-2019; Accepted: March-2019;

Avalaibel Online: March 2019; Published: March-2019)

(c) (8) This is an open access article distributed under the Creative Commons Attribution License CC-BY-NC-4.0 (2019 by author (https://creativecommons.org/licenses/by-nc/4.0/)

\begin{abstract}
The sector developed in Indonesia at this time is the tourism sector. The purpose of this study is to find out how the development of attractions, supporting and inhibiting factors, and formulate strategies in the development of tourism objects in Rejang Lebong Regency. This research uses descriptive research method with a qualitative approach. Data in this study were collected through interviews, documentation, observation and data triangulation. The analysis technique used in writing uses the SWOT analysis and Litmust Test to be reduced, presented and concluded. The results of research strategies for developing tourism objects in Rejang Lebong Regency are still not maximal, because there are many weaknesses in each component in the tourism area which become a benchmark for the development of Bengkulu Province tourist destinations, Rejang Lebong. The influencing factors are internal factors, namely strengths and weaknesses and external factors, namely opportunities and threats. Based on these factors, researchers can reformulate the strategy in the development of attractions in Rejang Lebong Regency, Bengkulu Province
\end{abstract}

Keywords: Strategy; development; tourist attraction.

\section{INTRODUCTION}

Indonesia is an island nation inhabited by a variety of different ethnic and racial tribes. Along with the passing of regional autonomy and its enactment (Law Number 23 of 2014 concerning Regional Government), there has been a change in the national government system. The change in the national government system can be seen from the principle of government, namely the change of principle which was originally centralized to become a decentralized principle. The purpose of decentralization is basically to hand over governmental authority by the Government to autonomous regions so that they can regulate and manage their own government affairs in the Unitary State of the Republic of Indonesia system (Riskasari, 2016; Simatupang \& Akib, 2011; Sirajuddin, 2016). 
District / city government is obliged to improve the welfare of the community in accordance with the conditions, uniqueness and superior potential of the region (Akib \& Niswaty, 2015) (Duadji, 2012; Nur Wijayanti, 2017; Widayat \& Probohudono, Agung, 2016). In developing tourism, local governments as the spearhead of the implementation of regional autonomy can make changes in the form of policies, for example in tourism, namely policies to develop regional tourism objects. Local governments also have a great opportunity to explore their potential and look for various sources of revenue that can finance local government expenditure in the context of organizing governance and development in various sectors (Abidin, 2015; Aziz, 2016; Putra, 2013). At the same time it also becomes a challenge for local governments to be independent and independent of dependence on the government as the executor of development, for example in tourism, which is a policy to develop regional tourism objects and be able to create a conducive climate for tourism practitioners so that they develop efficiently and effectively. Regional tourism development is also supported by the issuance (Law Number 10 Year 2009 on Tourism, 2009) stated that the authority of the regional government is to build, coordinate and organize provincial tourism.

The sector developed in Indonesia at this time is the tourism sector. Development is a long-term educational process utilizing systematic and organized procedures in which managers learn conceptual and theoretical knowledge for general purposes (Sikula, 2011; Snell, Shadur, \& Wright, 2017). Tourism is not only intended to provide pleasure to tourism, but tourism is also expected to be able to provide broad influence and change to the community, both in terms of social, economic, cultural and environmental (Buckley, 2012; Kadji, 2015; Prasodjo, 2017; Prosser, 2012). Supported by Law Number 10 of 2009 concerning Tourism with the aim of increasing national income, increasing development and introducing the tourist attraction of Indonesia. The objects and tourist attractions of each region have extraordinary advantages and their potential is very useful for the community (Gamal, 2004; Jupir, 2013; Sudana, 2013; Wiradiputra \& Brahmanto, 2016).

Rejang Lebong Regency is one of the regencies in Bengkulu Province. Administratively, Rejang Lebong Regency is bordered by Lebong Regency in the north, North Bengkulu Regency in the west and east of Musi Rawas Regency and in the south of Kepahiang Regency. Rejang Lebong Regency has a strategic location, this is because Rejang Lebong Regency is on the slopes of the Bukit Barisan mountain range $85 \mathrm{~km}$ from the city of Bengkulu, the provincial capital, giving an opportunity in Rejang Lebong Regency to further develop existing tourism objects.

However, the potential of these tourism objects has not been maximized in their use because there are still many obstacles in implementing the strategy for developing and managing tourism objects both from inside and outside, for example there have been no foreign tourist visits, Lack of facilities and infrastructure for tourism object development and lack of public support to participate as well as in developing tourist objects in their implementation. These constraints, if not immediately addressed, can hamper the development of the Rejang Lebong tourism industry. These constraints such as for example are still lacking public transportation facilities and the poor condition of the road used to get to tourist attractions. In addition there are also residents who do not care to maintain public facilities at the location of attractions that are marked by several public facilities to be damaged and can not be used optimally (Department of Culture and Tourism, 2015)

\section{METHOD}

The research method used is descriptive qualitative research method. The scope of the research is the development of attractions and strategies for developing tourist objects. The 
informants were 25 people consisting of: Head of the Rejang Lebong Regency Tourism Office, Head of the Tourism Office Secretariat, Head of the Tourism Destination Division, Head of Tourism Objects and Attraction Development Section, Head of Tourism Partnership and Institutional Section, Head of Tourism Business Cooperation Section Head, Head Tourism Facilities Management and Business, Head of Marketing, Head of Promotion Section, Head of Exhibition, Tourism Event and Cooperation, 5 tourism managers, and 10 tourists. Data collection techniques for interviews, documentation, and observation. The data validity technique used is concept triangulation, according to data sources and time triangulation. While the data analysis techniques are data reduction, data presentation and conclusion drawing.

\section{RESULT AND DISCUSSION}

Based on Law Number 10 of 2009 concerning Tourism, it is stated that the development of tourism can be seen from explaining that the development of tourism includes: industry, destinations, marketing (promotion), institutions, and facilities and infrastructure.

\section{Tourism Industry}

Based on the research results of the tourism industry found in Rejang Lebong Regency, it is still not optimally available. One of them is still not fulfilled, such as tourism service businesses, especially tourism consulting services, tour guide services, and spa businesses. This is due to several obstacles such as the lack of quality of Human Resources (HR) that can serve tourists in the field of consulting services, tour guides, and also spas. In addition, it is also due to budget constraints to provide wages to consultants, guides, and workers who work at the spa. But now, the Rejang Lebong Regency Tourism Office continues to strive to improve services in providing the best products or services for tourists to enjoy.

Rejang Lebong Regency does not have a travel agency yet; travel agent; tour guide services; convention services, incentive travel, and exhibitions; impressionist services; and tourism consulting services. Rejang Lebong Regency already has a tourism information service but it is still done individually.

\section{Destination Destinations}

Rejang Lebong Regency is one of the most strategic regencies in Bengkulu Province, there are many tourist destination areas or can be called tourism destinations have a special attraction to invite tourists to visit. However, for the time being the Regional Government together with the Rejang Lenong District Tourism Office manages only 3 attractions, namely DMHB, Bukit Kaba, and Suban Hot Springs.

As a tourist attraction and the connection between the taste by visitors so that they always come to a tourist destination especially the tourist attraction in Rejang Lebong Regency. The authority of the Provincial Government as an obligation must be carried out in article 29 of Law Number 10 Year 2009 on Tourism, namely compiling and stipulating development, coordinating the implementation, carrying out registration, recording and registering business registration, setting destinations, determining attractiveness, facilitating promotion, maintaining assets as a tourist attraction as well as allocating a budget. The program that has been implemented by the Bengkulu Province Tourism Office as an activity at the Tourist Destinations, namely: Bukit Kaba natural tourism, and cultural and historical tourism, batik tourism, agro tourism, and culinary tourism. 


\section{Promotion}

Tourism marketing or promotion efforts are usually carried out by attracting both through print media, electronic media, or other media as an attraction for tourists to visit tourist attractions. Promotion conducted by the Rejang Lebong Regency Tourism Office Yajkni advertising in conducting tourism promotion. Promotions are done through local television channels such as RB TV (Rakyat Bnegkulu TV), through the Bengkulu People's Daily Newspaper on special pages in Curup Pos, Radar Pat Petulai Newspaper, and several radio broadcasts such as Radio100 FM Diozz Curup, Radio 106.7 Four FM Curup, Radio 97.8 FM Namora Curup, and Radio 96.7 FM Swara Kelana Curup. In addition, Sales Support was also carried out in promoting tourism, one of which was through the provision of brochures containing information about tourism in Rejang Lebong Regency. The giving of this brochure is usually done at the time of the exhibition or certain events in order to commemorate the Curup City Anniversary every year. Based on the results of the study, tourism promotion efforts by the Rejang Lebong District Tourism Office are still not quite maximal due to several obstacles, such as the lack of quality human resources who are experts in using information and communication technology such as in managing official tourism websites, only a few employees understand how to manage the website.

\section{Tourism Object Development Strategy in Rejang Lebong Regency}

Rejang Lebong Regency has many tourism potentials that are very thick natural nuances in it contained uniqueness and distinctive features only Rejang Lebong Regency in Kaba hill nature tourism, Suban Hot Spring natural tourism, Lake Harum Bastari natural tourism so that the potential to compete with other regions cannot be denied the special attraction is naturebased tourism which is useful for visitors. Tourism Objects in Rejang Lebong Regency are very interesting, so many joys emerge especially the favored nature tourism. The meaning contained in the potential of tourist attraction is very useful for tourists to always preserve and protect tourists from sublime so exotic.

Supporting components in tourism infrastructure in this case in the fields of security, order, cleanliness, beauty, memories and information systems have been well done, only the implementation in Rejang Lebong Regency is still not fully felt. only a few houses near natural attractions neatly arranged with beautiful natural shades. Modern residential houses in Rejang Lebong Regency do not have the typical ethnic standards of Rejang, there are also facilities that are not maintained, such as the toilet ceiling in culinary green villas that are starting to perforate, wooden floors on the second floor are beginning to loose from its path so that the infrastructure still needs time as a support or supporter of the nature tourism kelestrain.

Rejang Lebong Regency is a very interesting and exotic tourist attraction concept in Bengkulu Province. Rejang Lebong Regency is a natural tourism center in Bengkulu. A place that can be found and felt natural nuances, tradition customs. The large number of tourism potentials in Rejang Lebong Regency which are being developed will make the future more and more a center of tourism for other regions to always maintain to be sustainably packaged so that they are more attractive. Enthusiastic tourists visit all tours of nature tourism, agro tourism, batik tourism and culinary tourism due to being a means of entertainment that can be enjoyed by natural beauty, getting to know culture for media education and socialization, besides introducing the characteristics of Rejang food that tastes very delicious. The increase in visitors can be a motivation for Rejang Lebong to continue to carry out tourism object development activities well and be able to compete with modern tourism objects in Indonesia with the 
existence of Rejang culture in Rejang Lebong Regency which will continue to be known by the entire community.

The potential in Rejang Lebong Regency is no longer doubted, especially in tourism objects, but it is sometimes constrained by people's homes that make it difficult for investors to invest their capital, the most unfortunate fear is that the community does not accept the architectural changes that have been provided by nature, fear in competitiveness in the business sector is also an inhibiting factor for investors who want to invest their capital. There are still many things that must be addressed in the natural tourism environment, making investors have to wait for a more conducive environment in order to create harmony to be safe between investors and the local community. Extensive management in Rejang Lebong Regency is not only managed by one Dinas but many Dinas, so that requires the Tourism Department in managing and developing in Rejang Lebong Regency must always coordinate with other Dinas so as to allow delays in development because it must be orderly administration between policies in each department. The entry of foreign cultures that are not appropriate is a threat that can affect virtuous people and eliminate cultures that have been inherited and then replaced by foreign cultures. This also has an impact on the loss of cultural uniqueness in the community especially in Rejang Lebong Regency. this can reduce the interest of tourists visiting the Tourism Objects in Rejang Lebong Regency.

\section{Supporting and Inhibiting Factors}

Tourism Objects in Rejang Lebong Regency are very interesting, so many joys emerge especially the favored nature tourism. The meaning contained in the potential of tourist attraction is very useful for tourists to always preserve and protect tourists from sublime so exotic. This is an attractive attraction that is characteristic of a regional area so that beauty and culture can be enjoyed as vacation stories. Based on observations of research conducted in the field, researchers observe employees in the field of partnerships and institutions that continue to review the tourism objects and the tourism environment that must always be preserved in the process of development, improvement, to maintenance. Objects that dance are Dynamic Regions which will be planned in the future to be more attractive to visitors and enhance the area. Improvement of lodging facilities that are based in natural attractions that are based in Mas Hraum Bastarai Lake Tourism, Suban hot spring nature tourism, Bukit Kaba Nature Tourism, publishing food sellers around tourist attractions, coordinating positions with related agencies that have responsibility for preservation of natural tourism. in Rejang Lebong Regency, fixing itself by cleaning up trash in the Danu Mas Harum Bastari tourist attraction and protecting the environment from rubbish and burning garbage, collecting data on communities that have comestible production houses, as well as souvenirs typical of Rejang Lebong and many other things to build tourist attraction to make it more interesting.

Modern residential houses in Rejang Lebong Regency do not have the typical ethnic standards of Rejang, there are also facilities that are not maintained, such as toilet ceilings in culinary green villas that are starting to perforate, wooden floors on the second floor that are starting to escape from the path so that the infrastructure still requires time as a support or supporter of the nature tourism kelestrain. Health facilities have not yet been seen, as a form of coping with tourists affected by a sudden disaster. As for transportation as for it is still difficult to reach tourist attractions that transportation equipment, especially this tour from the natural tourist gate of the hill Kaba does not exist so that requires visitors with public transportation vehicles such as public transportation must walk into the tour. The quality of human resources of tourism actors in Rejang Lebong Regency is still classified as inadequate. This is because most of the work arrangements in the Rejang Lebong Regency Tourism Office do not originate 
from tourism majors but rather come from social and economic majors. It was one of the benchmarks of disharmony between the majors of education in the area of work involved. The implementation of tourism promotion efforts in Rejang Lebong Regency is currently still lacking or not optimal due to the lack of a tourism information system, the lack of tourism marketing activities, the lack of utilizing the roles of two tours, and the real condition of the existing tourist attraction itself is not ready to promoted because of the conditions that are still very natural and the absence of renovations. There are still many things that must be addressed in the natural tourism environment, making investors have to wait for a more conducive environment in order to create harmony to be safe between investors and the local community.

\section{Formulation of Tourism Object Development Strategy in Rejang Lebong Regency, Bengkulu Province}

Strategies in developing Tourism Objects in Rejang Lebong Regency, Bengkulu Province namely; increase the potential, infrastructure and needs of attractions in Rejang Lebong Regency in Bengkulu Province in creating art, culture and business tourism based on natural tourism which can be one of the mainstays of the budget income for Rejang Lebong Regency in Bengkulu Province so that it will contribute to the welfare of the people of Bengkulu especially Rejang Lebong Regency community; utilizing technological developments, information and communication, enhancing human resource management and tourism development and in line with the vision and mission of the Rejang Lebong Tourism Office in Bengkulu Province in increasing public awareness of the importance of tourism potential owned by Rejang Lebong Regency with visitor satisfaction prioritized for visitors to always increasing every year. the latest technology, especially the role of telecommunications devices and social media influential in the promotion of leading tourism. Making Rejang Lebong Regency a Roll Mode of successful tourism and local wealth-based business areas for other regions; increasing tourism potential as much as possible, fixing the infrastructure as well as maximum care so that it can be enjoyed long-term and complete infrastructure to support the success of competing with other regions; improve the proper data collection and promotion of Tourism by providing tourism information systems, conducting tourism marketing activities by marketing the culture and potential of tourism in Rejang Lebong Regency, the beautiful Rejang cultural wealth with its characteristics by means of technological assistance with print technology such as newspapers, magazines, billboards other than that through electronic media such as making advertisements on local television and also advertising on the radio so that it remains to be seen and heard by the public in all aspects of improvement and development in the management of tourism and nature tourism and Rejang culture to attract investors; prevent the development of western culture that is not in accordance with the Rejang cultural character as a foundation for the development of Culture in Rejang Lebong Regency remains monsiten and in accordance with the vision and mission set by the Department of Tourism.

\section{CONCLUSION}

Rejang Lebong Regency Tourism Office Bengkulu Province undertook a development strategy with executive executives in charge of each line in the tourist attraction area in Rejang Lebong Regency to improve the quality of the area to make Rejang Lebong Regency an attractive and eductive destination for the visiting community. 


\section{REFERENCES}

Abidin, M. Z. (2015). Tinjauan Atas Pelaksanaan Keuangan Desa dalam Mendukung Kebijakan Dana Desa. Jurnal Ekonomi \& Kebijakan Publik. https://doi.org/http://dx.doi.org/10.22212/jekp.v6i1.156

Akib, H., \& Niswaty, R. (2015). Dampak Kebijakan Pemekaran Wilayah Terhadap Pengembangan Kompetensi Lokal Sebagai Basis Kerjasama Antar-Daerah Di Provinsi Sulawesi Barat.

Aziz, N. L. L. (2016). Otonomi Desa dan Efektivitas Dana Desa. Jurnal Penelitian Politik. https://doi.org/10.14203/JPP.V13I2.575

Buckley, R. (2012). Sustainable tourism: Research and reality. Annals of Tourism Research. https://doi.org/10.1016/j.annals.2012.02.003

Dinas Kebudayaan dan Parawisata. (2015). Rencana Induk Pengembangan Pariwisata Daerah.

Duadji, N. (2012). Good Governance dalam Pemerintah Daerah. MIMBAR, Jurnal Sosial dan Pembangunan. https://doi.org/10.29313/mimbar.v28i2.356

Gamal, S. (2004). Dasar-dasar Pariwisata. Yogyakarta: Andi, 2004. https://doi.org/10.15294/jejak.v7i1.3596

Jupir, M. M. (2013). Implementasi Kebijakan Pariwisata Berbasis Kearifan Lokal. of Indonesian Tourism and Development Studies.

Kadji, J. (2015). Optimalisasi Tata Kelola Sektor Pariwisata di Kabupaten Gorontalo. Jurnal Ad'ministrare: Jurnal Pemikiran Ilmiah dan Pendidikan Administrasi Perkantoran, 2(1), $1-15$.

Nur Wijayanti, S. (2017). Hubungan Antara Pusat dan Daerah Dalam Negara Kesatuan Republik Indonesia Berdasarkan Undang-Undang Nomor 23 Tahun 2014. Jurnal Media Hukum. https://doi.org/10.18196/jmh.2016.0079.186-199

Prasodjo, T. (2017). Pengembangan Pariwisata Budaya dalam Perspektif Pelayanan Publik. Jurnal Office, 3(1), 7-12.

Prosser, R. (2012). Tourism. In Encyclopedia of Applied Ethics. https://doi.org/10.1016/B978-012-373932-2.00072-7

Putra, C. (2013). Pengelolaan Alokasi Dana Desa Dalam Pemberdayaan Masyarakat Desa (Studi Pada Desa Wonorejo Kecamatan Singosari Kabupaten Malang)). Jurnal Administrasi Publik Mahasiswa Universitas Brawijaya.

Riskasari, R. (2016). Akuntabilitas Pengelolaan Alokasi Dana Desa di Desa Bongki Lengkese Kecamatan Sinjai Timur Kabupaten Sinjai. Jurnal Office, 2(2), 125-132.

Sikula, A. E. (2011). Manajemen Sumber Daya Manusia, Erlangga. Bandung. Gmjacs.

Simatupang, P., \& Akib, H. (2011). Efektivitas Implementasi dan Dampak Kebijakan dalam Konteks Desentralisasi Pemerintahan. Jurnal Ilmiah Ilmu Administrasi Publik: Jurnal Pemikiran dan Penelitian Administrasi Publik, 2(1), 1-9.

Sirajuddin, I. A. (2016). Implementasi Kebijakan Pemerintah Daerah dalam Pelayanan Publik Dasar Bidang Sosial di Kota Makassar. Jurnal Ilmiah Ilmu Administrasi Publik, 4(1), 114. 
Snell, S. A., Shadur, M. A., \& Wright, P. M. (2017). Human Resources Strategy. In The Blackwell Handbook of Strategic Management. https://doi.org/10.1111/b.9780631218616.2006.00024.x

Sudana, I. P. (2013). Analisis Pariwisata. Strategi Pengembangan Desa Wisata Ekologis Di Desa Belimbing, Kecamatan Pupuan Kabupaten Tabanan.

Undang-Undang Nomor 10 Tahun 2009 tentang Kepariwisataan. Undang-Undang Nomor 10 Tahun 2009 tentang Kepariwisataan. , (2009).

Undang-Undang Nomor 23 Tahun 2014 tentang Pemerintahan Daerah. Undang-Undang Nomor 23 Tahun 2014 tentang Pemerintahan Daerah. , (2014).

Widayat, W., \& Probohudono, Agung, N. (2016). Determinan Kesiapan Penerapan Sistem Akuntansi Berbasis Akrual Pada Pemerintah Daerah Di Indonesia. Simposium Nasional Akuntansi Xix, Lampung 2016.

Wiradiputra, F. A., \& Brahmanto, E. (2016). Analisis Persepsi Wisatawan Mengenai Penurunan Kualitas Daya Tarik Wisata Terhadap Minat Berkunjung. Pariwisata. 